\title{
Degradabilitas bahan organik dan produksi total Vollatile Fatty Acids (VFA) daun kelor (Moringa oleifera) dalam rumen secara in vitro
}

\author{
D. Nisa, J. Achmadi, and F. Wahyono \\ Fakultas Peternakan dan Pertanian, Universitas Diponegoro, Semarang. \\ Jalan Palebon 04 Kec. Pedurungan Kota Semarang Jawa Tengah \\ Correspondence author : diannisa123@gmail.com
}

\begin{abstract}
The research was aimed to examine nutritive potency of Moringa oleifera and Leucaena leucocephala leaves according to ruminal organic matter degradability and total volatille fatty acids production in vitro. The ruminal degradability of organic matter was determined after 1, 2, 4, 8, 12, 24 and 48 of single batch culture incubation. The data weretested using $\mathrm{T}$ test. The result showed that degradable and potential degradable fractions of $M$. oleifera leaf organic matter werehigher $(\mathrm{p}<0.05)$ than that of L. Leucocephala leaf organic matter Production of rumen total VFA from $M$. Oleifera leaf higher $(\mathrm{P}<0.05)$ than from $L$. leucocephala leaf. The nutritive potency of $M$. oleifera leaf was better than $L$. Leucocephala.
\end{abstract}

Keyword : Moringa leaves; leucaena leaf; VFA; in vitro.

\section{PENDAHULUAN}

Keberhasilan dalam usaha ternak kambing salah satunya harus dapat memenuhi ketersediaan pakan yang berkualitas, kuantintas dan memiliki harga yang murah. Hijauan pakan akan melimpah pada waktu musim penghujan namun pada musim kemarau sulit didapatkan, maka perlunya budidaya tanaman yang tahan terhadap musim salah satu diantaranya yaitu daun kelor. Kelor pertama kali tumbuh di negara India dan banyak juga dijumpai di Indonesia. Kelor dengan nama latin Moringa oleifera merupakan salah satu bahan pakan potensial bagi ruminansia karena memiliki sumber karbohidrat dan protein yang cukup tinggi yaitu kandungan BETN sebesar $32,83 \%$ serta PK 26,43 \%. Aminah et al. (2015) menyatakan bahwa daun kelor (Moringa oleifera) mengandung nutrien yang tinggi yaitu protein, karbohidrat, abu, lemak dan serat masing-masing sebesar 28,44; 57,01 ; 7,95 ; 2,74; dan $12,63 \%$. Daun kelor merupakan salah satu pakan potensial bagi ruminansia yang memiliki sumber protein yang tinggi sebesar $27 \%$ sehingga dapat meningkatkan produktivitas ternak (Jayanegara et al. 2010). Usman (2013) menyatakan bahwa ternak memerlukan pakan yang mengandung nutrient seperti karbohidrat, protein, lemak, vitamin, dan mineral untuk tubuhnya.

Karbohidrat diperlukan oleh tubuh ternak sebagai sumber energi dan sumber karbon untuk pembentukan protein mikroba. Produk akhir dari fermentasi karbohidrat dalam retikolorumen yaitu asam lemak mudah terbang atau yang biasa disebut volatile fatty acids (VFA). Amri dan Yurleni (2014) menyatakan bahwa VFA merupakan hasil fermentasi dari 
karbohidrat yang dibentuk oleh monosakarida dari hidrolisis selulosa oleh mikroba rumen. VFA terdiri dari asam asetat, propionate, butirat dan asam lemak rantai cabang. Asam asetat tersebut dapat digunakan oleh tubuh untuk proses lipogenesis (Usman, 2013).

Asam lemak bebas, gliserol dan galaktosa yang dibentuk dari proses lipolisis oleh enzim lipase rumen. Asam lemak bebas dihidrogenasi oleh mikroba rumen menjadi asam lemak jenuh sedangkan galaktosa dan glukosa di fermentasi menjadi VFA. Sugeng (2003) menyatakan bahwa karbohirat, protein dan metabolisme lemak merupakan sumber lemak bagi tubuh ternak. Karbohidrat dan protein yang sudah tidak dicerna akan dirubah menjadi lemak sedangkan sumber lemak yang terkandung dalam pakan akan dirubah menjadi pati dan gula untuk sumber energi dan sisanya digunakan untuk cadangan makanan.

Sebagai upaya untuk memaksimalkan potensi pemanfaatan daun kelor sebagai pakan, perlu adanya penelitian fermentabilitas dan degradabilitas bahan organik daun kelor sebagai pakan ternak kambing secara in vitro. Daun lamtoro sebagai pembanding. Fermentabilitas ruminal yang dimaksud adalah degredasi karbohidrat daun kelor dan daun lamtoro yang menjadi VFA.

\section{MATERI DAN METODE}

Penelitian menggunakan materi antara lain daun kelor, daun lamtoro dan cairan rumen dari kambing Jawarandu lokal betina berfistula (berumur 12-18 bulan dengan bobot badan $31,25 \mathrm{~kg}$ ). Kambing berfistula mendapatkan pakan dengan komposisi seperti yang ditunjukkan pada Tabel 1.

Tabel 1. Komposisi pakan kambing berfistula

\begin{tabular}{lccccc}
\hline \multicolumn{1}{c}{ Bahan pakan } & Formula & PK Bahan & PK Pakan & TDN Bahan & TDN Pakan \\
\hline & ------------------------------- & & \\
& 1,1 & 5,33 & 0,06 & 74,58 & 0,82 \\
Gaplek & 1,0 & 0,66 & 0,01 & 75,01 & 0,75 \\
Tetes & 17,0 & 35,97 & 6,11 & 81,10 & 13,79 \\
Bungkil kedelai & 10,7 & 9,70 & 1,04 & 67,48 & 7,22 \\
Bekatul & 0,2 & 0,00 & 0,00 & 0,00 & 0,00 \\
Mineral & 70,0 & 7,02 & 4,91 & 54,85 & 38,39 \\
Rumput gajah & 100 & \multicolumn{5}{c}{12,13} & 60,97 \\
\hline Jumlah & &
\end{tabular}

Uji in vitro dilakukan dengan teknik batch culture sesuai metode Tilley dan Terry (1963). Kandungan total VFA rumen dianalisis sesuai prosedur distilasi uap (General Laboratory Procedure, 1966). Pada penelitian ini, hasil uji in vitro daun kelor dibandingkan dengan daun lamtoro (Leucaena leucocephala). Degradasi bahan organik dihitung dengan persamaan eksponensial sesuai dengan metode Ørskov dan McDonald (1979).
Pembandingan antara degradabilitas BO dan fermentabilitas VFA pada kelor dan lamtoro dilanjutkan dengan uji $\mathrm{T}$ test.

\section{HASIL DAN PEMBAHASAN}

\section{Degradabilitas bahan organik secara in vitro}

Hasil penelitian degradabilitas bahan organik secara in vitro disajikan pada Tabel 2. dan Ilustrasi 1. 
Kecepatan degradasi semakin meningkat seiring dengan semakin lamanya waktu inkubasi (Ilustrasi 1). Persentase kehilangan bahan organik daun kelor menunjukan lebih tinggi daripada daun lamtoro. Semakin lama waktu inkubasi bahan pakan maka persentase kehilangan bahan pakan yang dihasilkan semakin meningkat. Hal ini menunjukkan bahwa mikroba rumen mendegradasi bahan pakan daun

kelor lebih cepat pada interval waktu yang telah ditentukan dibanding daun lamtoro. Semakin lama bahan pakan berada dalam rumen akan semakin lama pula mikroba mendegradasi pakan sehingga ketersediaan pakan dalam rumen menurun. Suhartanto dkk. (2000) menyatakan bahwa berkurangnya jumlah substrat yang tersedia dapat dipengaruhi oleh lamanya waktu inkubasi.

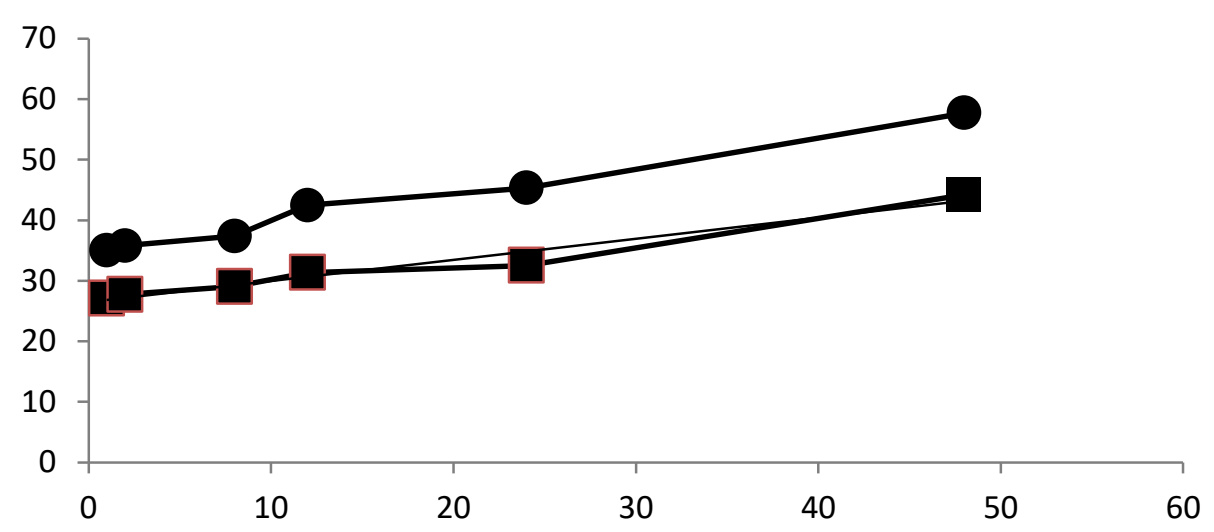

Ilustrasi 1. Laju Degradabilitas Bahan Organik Daun Kelor ( $)$ dan Daun Lamtoro (ם) secara In Vitro

Adanya perbedaan tingkat persentase kelarutan/kehilangan bahan organik pada daun kelor maupun daun lamtoro. Pada penelitian ini dapat dipengaruhi oleh sumber karbohidrat yang mudah terdegradasi pada kelor yang lebih tinggi dari lamtoro dan kandungan Acid Detergent Fibre (ADF) kelor lebih rendah daripada daun lamtoro. Tinggi rendahnya ADF yang diperoleh akan menentukan mudah tidaknya degredasi pada selulosa lignin. Hasil analisis kandungan NDF dan ADF antara daun kelor dan daun lamtoro yang telah diuji diperoleh $22,75 \%$ dan 15,57 serta $28,19 \%$ dan $23,38 \%$. Sudirman dkk. (2015) menyatakan bahwa kandungan ADF yang rendah maka kecernaan pakan akan tinggi, hal ini dikarenakan kadar lignin yang meningkat sehingga kadar hemiselulosa menurun. Hemiselulosa dan selulosa bagian dari komposisi dinding sel yang dapat dicerna oleh mikroba. Pada Tabel 2. menunjukan nilai degradabilitas bahan organik fraksi a (fraksi cepat larut) menunjukan adanya pengaruh nyata $(\mathrm{p}<0,05)$ pada kelor dan lamtoro. Fraksi a yang lebih tinggi pada daun kelor sebesar $31,08 \%$ dibandingkan lamtoro 23,43\%. Hal ini dapat dikarenakan oleh kandungan isi sel seperti mineral, protein kasar, lemak kasar dan pati yang mudah larut pada kelor sebesar $77,25 \%$ lebih tinggi dibandingkan daun lamtoro sebesar $71,81 \%$. 
Tabel 2. Rata - rata nilai degradasi bahan organik fraksi a, b, c dan DT daun kelor dan daun lamtoro.

\begin{tabular}{lcc}
\hline \multirow{2}{*}{ Variabel } & \multicolumn{2}{c}{ Bahan pakan } \\
\cline { 2 - 3 } & Kelor & Lamtoro \\
\hline $\mathrm{a}(\%)$ & $31,08^{\mathrm{a}}$ & $23,43^{\mathrm{b}}$ \\
$\mathrm{b}(\%)$ & $38,71^{\mathrm{a}}$ & $29,64^{\mathrm{b}}$ \\
$\mathrm{c}(\% /$ jam $)$ & 4,70 & 4,84 \\
DT $(\%)$ & $48,12^{\mathrm{a}}$ & $36,36^{\mathrm{b}}$ \\
\hline
\end{tabular}

Keterangan:

1. $\mathrm{a}(\%)=$ Nilai fraksi $\mathrm{a} ; \mathrm{b}(\%)=$ Nilai fraksi $\mathrm{b} ; \mathrm{c}(\% / \mathrm{jam})=$ Nilai fraksi $\mathrm{c}$ dan DT $(\%)=$ Nilai DT pada daun kelor dan lamtoro.

2. Superskrip ${ }^{\mathrm{a}, \mathrm{b}}$ pada baris yang sama menunjukan berbeda nyata $(\mathrm{P}<0,05)$.

Degradabilitas bahan organik fraksi $b$ daun kelor lebih tinggi $(\mathrm{p}<0,05)$ daripada daun lamtoro. Tingginya nilai fraksi $b$ pada daun kelor dapat disebabkan oleh kandungan serat seperti lignin, selulosa maupun hemiselulosa yang lebih banyak dibandingkan daun lamtoro. Dapat diketahui analisis kimia kompononen serat hemiselulosa kelor sebesar 7,18\% lebih tinggi dibandingkan daun lamtoro sebesar $4,81 \%$. Namun, pada degradabilitas bahan organik fraksi c tidak ada perbedaan nyata $(p>0,05)$ antara daun kelor dan daun lamtoro. Hal ini dapat dipengaruhi oleh kualitas serat yang terkandung di dalam suatu bahan pakan dari nilai yang dihasilkan pada fraksi c. Suhartanto et al. (2000) menyatakan bahwa kandungan nutrien dalam bahan pakan dapat menentukan kemampuan mikrobia rumen untuk mendegradasi pakan sehingga dapat mempengaruhi kecernaan pakan pada ternak terutama kandungan ligninnya.

Degradabilitas bahan organik DT daun kelor lebih tinggi $(\mathrm{p}<0,05)$ daripada daun lamtoro. Hal ini dikarenakan oleh adanya pengaruh dari nilai fraksi a, b dan c. Salah satu pengaruh dari peningkatan aktivitas mikrobia selulolitik dalam rumen yaitu banyaknya substrat serat kasar yang tersedia. Semakin tinggi serat yang tersedia maka nilai fraksi a, b dan c pun akan meningkat dan menyebabkan nilai DT menjadi tinggi. Pamungkas dan Utomo (2008) menyatakan bahwa nilai fraksi a (mudah larut), fraksi b (potensial degradasi), nilai c (laju degradasi fraksi b) dan laju aliran pakan keluar dari rumen dapat digunakan untuk menghitung fraksi DT.

\section{Produksi Total Vollatile Fatty Acids secara In Vitro}

Hasil penelitian produksi total VFA secara in vitro dari daun kelor dan lamtoro pada waktu 4 jam inkubasi yang diuji menggunakan uji $\mathrm{T}$ ( $\mathrm{T}$ test) dengan bantuan program SPSS For Windows Versi 17 disajikan pada Tabel 3. Periode 4 jam inkubasi yang dilakukan secara in vitro pada daun kelor dan daun lamtoro menunjukan tidak ada pengaruh nyata (p>0,05). Hasil produksi total VFA daun kelor yaitu 76,67 $\mathrm{mM}$ lebih tinggi $(\mathrm{p}<0,05)$ dibandingkan VFA daun lamtoro yaitu 73,33vmM. 
Tabel 3. Produksi total VFA rumen secara in vitro dari daun kelor dan lamtoro pada 4 jam inkubasi.

\begin{tabular}{|c|c|}
\hline \multirow{2}{*}{ Bahan pakan } & Periode inkubasi \\
\hline & 4 jam \\
\hline & ----------------------mM--------------------- \\
\hline Daun kelor & $76,67^{\mathrm{a}}$ \\
\hline Daun lamtoro & $73,33^{\mathrm{b}}$ \\
\hline
\end{tabular}

Keterangan: Superskrip ${ }^{\mathrm{a}, \mathrm{b}}$ pada kolom yang berbeda menunjukan tidak berbeda nyata $(\mathrm{P}>0,05)$.

Salah satu sumber energi utama bagi ruminansia dan perkembangan mikroba rumen adalah volatille vatty acids (VFA). Produksitotal VFA tidak berpengaruh nyata $(\mathrm{p}>0,05)$ antara bahan pakan kelor dan lamtoro terhadap periode inkubasi 4 jam. Hal ini menunjukkan bahwa adanya aktivitas mikroba antara daun kelor dan daun lamtoro hampir sama. Diketahui produksi total VFA daun kelor lebih tinggi dibandingkan pada daun lamtoro. Hasil analisis kimia diperoleh serat kasar daun kelor yang lebih rendah daripada lamtoro $23,58 \%$ dan $30,63 \%$ serta kandungan BETN kelor yang lebih tinggi yaitu $32,83 \%$ dibandingkan dengan BETN daun lamtoro sebesar $23,60 \%$. Hal tersebut menunjukan sumber karbohidrat yang terdegradasi lebih tersedia di daun kelor. France dan Dijkstra (2005) menyatakan bahwa ada beberapa faktor yang mempengaruhi tinggi rendahnya dari konsentrasi VFA antara lain bentuk fisik pakan, tipe jumlah karbohidrat yang mudah larut, pH rumen, kecernaan bahan pakan, pakan basal dan penambahan zat aditif kimia dalam pakan.

Kadar total VFA daun kelor dan daun lamtoro adalah $76,67 \mathrm{mM}$ dan $73,33 \mathrm{mM}$. Konsentrasi VFA optimumnya rataannya adalah $80-160$ $\mathrm{mM}$ namun hasil penelitian menunjukkan rataan produksi VFA dibawah rataan optimum sehingga berpengaruh tidak nyata dan belum dapat memenuhi kebutuhan VFA untuk sintesis. Menurut Indriani (2013) bahwa kadar VFA optimum antara $80 \mathrm{mM} \mathrm{-}$ $160 \mathrm{mM}$. Karbohidrat yang terfermentasi menghasilkan VFA dimana VFA digunakan sebagai sumber energi bagi ternak ruminansia. Jumlah VFA yang dihasilkan menunjukkan kemampuan pakan untuk terdegradasi oleh mikroba rumen.

\section{KESIMPULAN}

Degradabilitas bahan organik dan produksi total VFA daun kelor lebih tinggi daripada daun lamtoro sehingga potensi nutritif daun kelor $(M$. oleifera)lebih baik dari daun lamtoro ( L. leucocephala).

\section{DAFTAR PUSTAKA}

Aminah, S., T. Ramdhan dan M. Yanis. 2015. Kandungan nutrisi dan sifat fungsional tanaman kelor (Moringa oleifera). Buletin Pertanian Perkotaan, 5 (2) : 35 $-44$.

Amri, U dan Yurleni. 2014. Efektivitas pemberian pakan yang mengandung minyak ikan dan olahanya terhadap fermentasi rumen secara in vitro. Jurnal Ilmiah Ilmu-Ilmu Peternakan, 62 (1) : 22-30.

France J., and J. Dijkstra. 2005. Volatile fatty acid production. Quantitative Aspects of Ruminant Digestion and Metabolism. 
Dijkstra J, Forbes JM, France J, editors CABI. Wallingford, United Kingdom : 157-176.

General Laboratory Procedures. 1966. Departement of Dairy Science. University of Wisconsin, Madison.

Haryanto, B. 2012. Perkembangan penelitian nutrisi ruminansia. Wartazoa, 22 (4) : 169-177.

Indriani, N., T. R. Sutardi dan Suparwi. 2013. Fermentasi limbah soun dengan menggunakan Aspergillus niger ditinjau dari kadar volatile fatty acid (VFA) total dan amonia $\left(\mathrm{NH}_{3}\right)$ secara in vitro. Jurnal Ilmiah Peternakan, 1(3): 804812.

Jayanegara, A., T. Sabhan, A. K. Takyi, A. O. Salih and E. M. Hoffmann. 2010. Ruminal fermentation kinetics of Moringa and Peltiphyllum Supplements during early incubation period in the in vitro. Reading pressure technique. J. Indonesian Trop. Anim. Agric., 35(3) : 165-171.

Ørskov, E. R. and I. McDonald. 1979. The estimation of protein degradabality in the rumen from incubation measurements weightaccording to rate of passage. J. Agric. Sci. Comb., 92 : $499-503$.

Pamungkas, D. dan R. Utomo. 2008. Kecernaan bahan kering in sacco tumpi jagung dan kulit kopi substrat tunggal dan kombinasi sebagai pakan basal sapi potong. Dalam: Syafitrie, C., L. Yunia, E. Kelonowati dan Muladi. Prosiding Seminar Nasional dan Teknologi dan Veteriner : 205211.

Sudirman, Suhubdy, S. D. Hasan, S. H. Dilaga, dan I. W. Karda. 2015. Kandungan Neutral Detergent Fibre (NDF) dan Acid Detergent Fibre (ADF) bahan pakan lokal ternak sapi yang dipelihara pada kandang kelompok. J. Ilmu dan Teknologi Peternakan Indonesia, 1 (1) : 66-70.

Suhartanto, B., Kustantinah dan S. Padmowijoto. 2000. Degradasi in sacco bahan organik dan protein kasar empat macam bahan pakan diukur menggunakan kantong intra dan rowett Research Institute. Buletin Peternakan, 24(2) : 8293.

Tilley, J.M.A. and R.A., Terry. 1963. A two stage technique for the in vitro digestion of forage. $J$. British Grassland Soc., 18 : 104-111.

Usman, Y. 2013. Pemberian pakan serat sisa tanaman pertanian (jerami kacang tanah, jerami jagung, pucuk tebu) terhadap evolusi $\mathrm{pH}$, $\mathrm{N}-\mathrm{NH} 3$ dan VFA di dalam rumen sapi. J. Agripet, 13(2) : 53-58. 